\title{
PERANCANGAN ALAT PENDETEKSI KELAYAKAN OLI PADA KENDARAAN SEPEDA MOTOR BERBASIS ARDUINO UNO ATMEGA328
}

\author{
Muhammad Irsyam ${ }^{1)}$, Prist Sadarsyah ${ }^{2)}$ \\ ${ }^{1,2}$ Program Studi Teknik Elektro, Fakultas Teknik, Universitas Riau Kepuluan Batam \\ Email : irsyam.muaz1@gmail.com,
}

\begin{abstract}
Abstrak
Pada kendaraan bermotor pelumasan adalah suatu hal yang sangat penting. Pelumasan berfungsi untuk melumasi komponen logam atau metal yang bergesekan dalam mesin. Untuk menjaga performa mesin kendaraan tetap prima maka kita harus cermat dalam memilih jenis oli yang akan digunakan menurut tingkat kekentalan oli yang dibutuhkan oleh kendaraan yang kita gunakan. Selain itu pemeriksaan dan pergantian oli secara berkala berperan penting dalam menjaga awetnya mesin kendaraan.

Untuk membantu dalam pengecekan oli bagi para pemilik kendaran bermotor dalam hal ini sepeda motor dalam itu peneliti merancang sebuah alat pendeteksi kelayakan oli pada kendaraan sepeda motor. Perubahan nilai resistansi dari sensor IR (Infrared Resistor) setelah menerima pantulan cahaya dari LED (Light Emitting Diode) yang diletakkan diatas permukaan oli menyebabkan tegangan yang diterima Arduino Uno microcontroller ATmega328 membaca perubahan warna oli pada sebuah baki oli sepeda motor.
\end{abstract}

Kata kunci : Pengecekan oli, Pantulan cahaya LED, Arduino Uno

\begin{abstract}
Lubrication in motor vehicles is important, lubrication is not only serves to lubricate metal or metal touching or friction in the machine. To maintain the performance of the vehicle's engine is prime, we must carefully select the type of oil to be used according to the oil viscosity level required by the vehicle we use. In addition, inspection and oil change periodically play an important role in maintaining the vehicle's crew.

To assist in oil checking for motorised owners in this motorcycle in this case the author devised an oil feasibility detection tool on a motorcycle vehicle. Changes in resistance value from IR sensor (Infrared Resistor) after receiving light reflection from LED (Light Emitting Diode) that is placed above the oil surface causing the received voltage Arduino Uno Microcontroller ATmega328 Read the changes Oil color on a motorcycle oil tray.
\end{abstract}

Keywords: Oil checking, LED light reflection, Arduino Uno 


\section{PENDAHULUAN}

Pada kendaraan bermotor pelumasan (lubrikasi) merupakan salah satu hal yang sangat penting. Selain berfungsi sebagai peredam gesekan antara logam atau metal dalam mesin, proses pelumasan juga ikut berperan dalam menjaga suhu mesin selain cooling sistem, meredam suara mesin sekaligus membersihkan komponen mesin. Ketika minyak pelumas melapisi permukaan logam dengan sempurna maka keadaan optimum pada kendaraan dapat tercapai karena semakin kecil gesekan pada logam yang digunakan dalam mesin kendaraan.

Bahan aditif merupakan zat kimia tertentu yang dicampurkan pada pelumas yang dapat meningkatkan kualitas pelumas selain dihasilkan oleh proses pengolahan dan pemurnian yang baik dari pelumas tersebut. Penambahan aditif dalam minyak pelumas bukan cara mudah karena minyak pelumas akan bereaksi dengan aditif tersebut, dan juga aditif tersebut akan akan mempengaruhi aditif lainnya.

Untuk menjaga performa mesin kendaraan tetap prima maka kita harus cermat dalam memilih jenis oli yang akan digunakan menurut tingkat kekentalan oli yang dibutuhkan oleh kendaraan yang kita gunakan. Selain itu pemeriksaan dan pergantian oli secara berkala berperan penting dalam menjaga awetnya mesin kendaraan. Namun sangat disayangkan pada masa sekarang ini sering sekali kita menemukan banyak kendaraan terutama sepeda motor mengalami kerusakan mesin akibat kelalaian pengguna kendaraan dalam memelihara dan mengganti oli secara tepat waktu. Selain itu kurangnya pemahaman masyarakat dalam mengetahui kelayakan dari oli yang ada pada kendaraannya masih minim. Disamping itu bengkel pada umumnya untuk menentukan pergantian oli berdasarkan range waktu pemakaian kendaraan padahal hal tersebut bukanlah hal yang tepat untuk menentukan waktu pergantian oli pada kendaraan. Tidak jarang kita jumpai beberapa oknum mekanik yang curang dan tidak teliti dalam melihat kondisi oli pada kendaraan yang diservis demi peningkatan penjualan produk oli dari bengkel mereka. Untuk membantu dalam pengecekan oli bagi para pemilik kendaran bermotor dalam hal ini sepeda motor dalam itu peneliti membuat judul skripsi Perancangan Alat Pendeteksi Kelayakan Oli Pada Kendaraan Bermotor Berbasis Arduino Uno Atmega328. Selain untuk mengetahui kualitas oli, dapat diterapkan pada bengkel yang ada untuk melihat kualitas oli dengan alat ini. Sehingga memudahkan kinerja bengkel dalam pelayanan servis.

Dengan membaca dan mempelajari penelitian sebelumnya menggunakan sensor kapasitif pada alat pengukuran kualitas oli berbasis fuzzy logic. Selain itu juga mempelajari penelitian pengukuran visikositas oli motor 4 tak menggunakan cahaya laser. Peneliti memilih menggunakan sensor IR yang lebih sederhana dan praktis untuk mengetahui kelayakan dari oli berdasarkan perubahan warna dari oli kendaraan sepeda motor. Perubahan nilai resistansi dari sensor IR (Infrared Resistor) setelah menerima pantulan cahaya dari LED (Light Emitting Diode) yang diletakkan di atas permukaan oli menyebabkan tegangan yang diterima dikonversikan secara ADC (Analog Digital Converter) oleh controller Arduino Uno. Sebagai output akhir dari peralatan ini akan menyatakan apakah oli dalam motor tersebut masih layak atau tidak layak digunakan yang akan ditampilkan pada sebuah LCD.

\section{LANDASAN TEORI}

\section{A. Tinjauan Pustaka}

Oli adalah pelumas (lubricant) yang digunakan pada kendaraan bermotor. Fungsi pelumas adalah untuk mengurangi tingkat keausan akibat gesekan antar komponen mesin pada saat bekerja. Dalam praktek kehidupan sehari-hari, penentuan umur pakai oli hanya bergantung pada durasi pemakaian dan jangkauan jarak yang tampak pada speedometer.

Jarak tempuh dari sebuah kendaraan menjadi salah satu pedoman untuk menyatakan kelayakan dari oli. Berdasarkan buku pedoman penggunaan kendaraan bermotor. Hal ini sesuai dengan buku petunjuk pemakaian 
kendaraan sepeda motor pergantian oli wajib dilakukan setelah perjalanan $3000 \mathrm{~km}$ sekaligus melakukan servis berkala untuk menjaga performa mesin dalam kondisi baik.

Perubahan warna dan kekentalan pada oli mengakibatkan perubahan intesitas cahaya yang dipantulkan oleh permukaan oli. Ketika cahaya diarahkan pada permukaan oli maka akan terjadi proses pembiasan dan pemantulan. $\mathrm{Hal}$ ini memungkinkan cahaya dapat terpolarisasi sebagian atau mengalami refleksi seluruhnya. Reflektansi (R) merupakan perbandingan intensitas cahaya yang dipantulkan dengan cahaya yang datang, sedangkan transmitansi (F) merupakan perbandingan intensitas cahaya yang ditransmisikan dengan cahaya datang. Pada penelitian yang dilakukan oleh ilmuan Fresnel dapat dirumuskan suatu persamaan koefisien refleksi dan koefisien transmisi yang dihasilkan oleh pemantulan dan pembiasan. Salah satu sensor yang dapat digunakan untuk membaca perubahan intesitas cahaya yang dipantulkan oleh suatu benda adalah sensor IR. Pada sensor IR terdapat dua bagian penting yaitu LED yang berperan sebagai transmitter emmiter dan photodiode sebagai receiver reflector. Photodiode memiliki cara kerja dimana resistansinya berubah-ubah sesuai dengan intensitas cahaya yang diterima olehnya, karena sebenarnya suatu proton dapat mendorong elektron bebas untuk menyeberangi persambungan pn junction, dan menyebabkan arus mengalir.

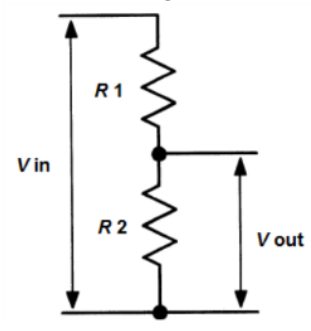

Gambar 1 Rangkaian Pembagi Tegangan

Dengan adanya dua resistor yang dihubungkan secara seri maka tegangan input dan tegangan output dibagi secara proporsional sesuai dengan nilai resistansi pada resistor sesuai dengan rumus :

Vout $=\frac{\mathrm{R} 2}{\mathrm{R} 1+\mathrm{R} 2} \times \mathrm{V}$ in
Dari rumus diatas maka dapat diperoleh persamaan untuk menentukan nilai R2 jika yang diketahui nilai tegangan input, tegangan output dan resistansi R1 sebagai berikut :

$$
\frac{\text { Vin }}{\text { Vout }} \times \mathrm{R} 2-\mathrm{R} 2=\mathrm{R} 1
$$

Keterangan :

Vin : Tegangan masukan pada rangkaian sensor photodiode

Vout : Tegangan keluaran pada rangkaian sensor photodiode

R1 : Resistansi yang terdapat pada rangkaian dioda

R2 : Resistansi yang terdapat pada photodiode

\section{B. Arduino Uno}

Arduino Uno merupakan board yang memiliki 14 pin input / output berbasis mikrokontroler pada ATmega328 dimana 6 pin dapat digunakan sebagai output PWM, 6 pin sebagai input analog, $16 \mathrm{MHz}$ osilator kristal, koneksi USB, dan dengan tombol reset.

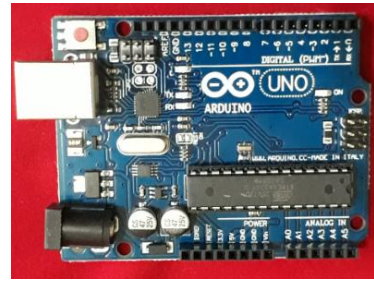

\section{Gambar 2 Arduino Uno}

Semua pin dapat digunakan sesuai dengan kebutuhan rangkaian yang diinginkan dan juga diperlukan untuk mendukung mikrokontroler. Sumber tegangan dapat dengan mudah diperoleh yaitu dengan menghubungkannya pada komputer melalui port USB, dengan menggunakan baterai ataupun sumber tegangan adaptor AC-DC.

Sesuai dengan namanya kata uno diambil dari bahasa Italia yang berarti satu. Hal ini menandakan produk keluaran dengan versi 1.0 dan akan berkelanjutan pada versi selanjutnya bahwa Arduino Uno berarti satu dalam bahasa Italia dan dinamai untuk menandakan keluaran (produk) Arduino Uno 
1.0 selanjutnya. Arduino Uno merupakan seri terakhir dari board Arduino Uno USB dan model referensi untuk papan Arduino Uno, untuk suatu perbandingan dengan versi sebelumnya. Untuk lebih memahami tentang spesifikasi Arduino Uno dapat dilihat pada tabel 1 .

Tabel 1 Deskripsi Arduino Uno

\begin{tabular}{|l|l|}
\hline Mikrokontroller & Atmega328 \\
\hline Operasi Voltage & $5 \mathrm{~V}$ \\
\hline Input Voltage & $7-12 \mathrm{~V}$ (Rekomendasi) \\
\hline Input Voltage & $6-20 \mathrm{~V}$ (Limits) \\
\hline I/ O & 14 pin (6 pin untuk PWM) \\
\hline Arus & $50 \mathrm{~mA}$ \\
\hline Flash Memory & $32 \mathrm{~KB}$ \\
\hline Boot Loader & SRAM $2 \mathrm{~KB}$ \\
\hline EEPROM & $1 \mathrm{~KB}$ \\
\hline Kecepatan & $16 \mathrm{Mhz}$ \\
\hline
\end{tabular}

\section{a. Komunikasi}

Arduino dilengkapi dengan beberapa fasilitas dalam berkomunikasi dengan komputer, Arduino lain, atau mikrokontroler lain. Pada mikrokontroler ATmega328 menyediakan UART TTL (5V) komunikasi serial, yang tersedia pada pin Digital 0 (RX) dan 1 (TX). Perangkat lunak Arduino Uno termasuk monitor serial yang memungkinkan data sederhana yang akan dikirim ke board Arduino Uno. Ketika data sedang dikirim melalui chip USB-to-serial dan koneksi USB ke komputer maka lampu LED RX dan TX pada board akan berkedip.

\section{b. Programming}

Untuk menggunakan Arduino diperlukan suatu program yang berisi perintah sesuai dengan rancangan yang diinginkan. Program ini harus dibuat dengan suatu perangkat lunak yang disebut Arduino IDE. Arduino IDE merupakan sebuah aplikasi yang digunakan untuk membuat program yang nantinya akan dimasukkan ke dalam mikrokontroler. Dengan program tersebut, diharapkan nantinya mikrokontroler dapat melakukan proses sesuai dengan yang diinginkan. Saat membuat program, bahasa yang digunakan adalah bahasa $\mathrm{C}$ yang merupakan salah satu bahasa pemrograman yang telah dikenal luas di kalangan programmer.

Pada Arduino IDE, disediakan beberapa tombol pada toolbar nya. Berikut ini adalah penamaan tombol tersebut beserta fungsinya.

1) New, digunakan dalam membuat sketch baru.

2) \pm Open, digunakan dalam membuka sketch yang sudah pernah tersimpan dalam file sebelumnya.

$3) \rightarrow$ Upload, digunakan untuk mentransfer kode program dari Arduino IDE ke perangkat keras Arduino.

4) $₫$ Save, digunakan untuk menyimpan sketch di lokasi yang diinginkan.

5) Verify, digunakan untuk memeriksa kode program yang sudah dibuat, apakah masih terdapat atau tidak terdapat kesalahan.

Gambar 3 merupakan salah satu frame work pada sebuah program Arduino.

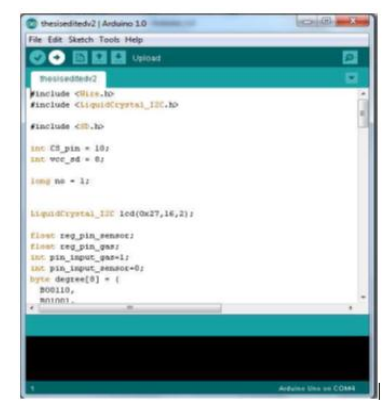

Gambar 3 Frame Work Arduino Uno

c. Otomatis software reset 
Pada Arduino terdapat tombol reset yang dirancang untuk menjalankan program yang tersimpan didalam mikrokontroller dari awal. Tombol tersebut akan terhubung dengan mikrokontroler Atmega328 melalui kapasitor 100nf. Untuk me-reset chip cukup dengan menekan tombol reset dalam beberapa detik.

\section{Bahasa C}

Dalam dunia pemrograman bahasa $\mathrm{C}$ merupakan bahasa pemrograman yang cukup dikenal dapat digunakan dalam berbagai pembuatan aplikasi seperti perangkat lunak pada pengolah gambar (image processing), anti virus, sistem operasi berupa Windows maupun Linux, hingga compiler untuk bahasa pemrograman.

Diperlukan instruksi yang terstruktur dalam merancang sebuah program $\mathrm{C}$ dalam menciptakan sebuah sistem. Berikut merupakan instruksi utama yang merupakan dasar pada perancangan sistem menggunakan program $\mathrm{C}$ :

1) \{\} , bracket digunakan untuk memblok statement atau perintah yang kita inginkan.

2) \#include $<>$, perintah ini merupakan bagian awal pada sebuah sistem. Pada bagian ini kita menyatakan file header atau library apa yang akan kita gunakan.

3) $\operatorname{main}()$, perintah ini akan menjadi fungsi utama dari bahasa $\mathrm{C}$.

4) return 0 ; , perintah untuk mengembalikan nilai int main menjadi 0 .

5) statement, bagian ini menjadi tempat menentukan identifikasi, variabel sekaligus fungsi pada suatu program yang dirancang.

\section{Sumber Tegangan}

Untuk mendapatkan sumber tegangan pada Arduino Uno maka dapat diperoleh melalui catu daya eksternal ataupun langsung dihubungkan dengan USB komputer. Pada sumber eksternal atau non- USB daya dapat datang baik dari AC-DC adaptor atau baterai. Arduino dapat beroperasi dengan menggunakan sumber tegangan mulai dari 6 volt hingga 20 volt. Jika diberikan dengan kurang dari $6 \mathrm{~V}$ menyebabkan pin $5 \mathrm{~V}$ dapat menyuplai kurang dari 5 volt dan board mungkin tidak stabil. Jika menggunakan lebih dari $12 \mathrm{~V}$, regulator tegangan bisa panas dan merusak board. Rentang yang dianjurkan adalah 6 - 12 volt. Lead dari baterai dapat dimasukkan ke dalam header pin Gnd dan Vin dari konektor power dan untuk menghasilkan tegangan dan arus DC (arus searah) yang kostan dan stabil, diperlukan voltage regulator yang berfungsi untuk mengatur tegangan sehingga tegangan output tidak dipengaruhi oleh suhu, arus pada beban dan juga tegangan input yang berasal output filter. Voltage regulator pada umumnya terdiri dari dioda Zener, transistor atau IC (Integrated Circuit).

Pada DC Power supply yang canggih, biasanya voltage regulator juga dilengkapi dengan pelindung terhadap hubung singkat (Short Circuit Protection), pembatas arus berlebih (Current Limiting) ataupun pelindung terhadap tegangan berlebih (Over Voltage Protection).

Terdapat tiga pin utama pada catu daya. Pin catu daya yang dimaksud adalah sebagai berikut:

1) $5 V$. Catu daya diatur untuk digunakan sebagai daya pada mikrokontroler dan komponen lainnya di board. Hal ini dapat terjadi baik dari sumber tegangan melalui regulator eksternal atau diberikan oleh USB .

2) VIN. Tegangan input ke board Arduino Uno ketika menggunakan sumber daya eksternal (sebagai lawan dari 5 volt dari koneksi USB atau sumber daya lainnya diatur). Kita dapat menyediakan tegangan melalui pin ini atau jika memasok tegangan melalui colokan listrik mengaksesnya melalui pin tersebut.

3)GND. Grounding berguna dalam mengurangi cacat (noise) yang disebabkan baik oleh pasokan daya yang kurang stabil, gangguan surya petir ataupun kualitas komponen yang tidak standar.

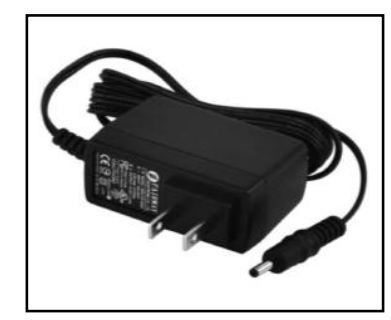

Gambar 4 Catu daya / DC power adaptor 


\section{a. Regulator $78 \mathrm{XX}$}

Komponen IC 78xx merupakan salah satu keluarga IC regulator tegangan yang mudah penggunaanya, murah dalam segi harga dan dapat digunakan dalam sirkuit elektronik yang membutuhkan power supply yang dapat diatur. Kode angka pada IC ini memiliki pengertian yang berbeda sesuai dengan kebutuhan penggunanya. Kode angka dua digit di depan yaitu 78 atau 79 menunjukkan jenis tegangan regulator yang bekerja. Kode 78 menyatakan regulator bekerja pada tegangan positif dan kode 79 menunjukkan regulator bekerja pada tegangan negatif. Untuk mendapatkan tegangan kombinasi pada satu sirkit board maka dapat digunakan kedua jenis ini pada satu rangkaian board. Sedangkan dua angka dibelakang menunjukkan besar output tegangan misalnya IC7812 tegangan output 12 volt sementara IC7805 menghasilkan tegangan output 5 volt. Gambar 5 menunjukkan persamaan rangkaian voltage regulator yang menggunakan IC Regulator 78XX.
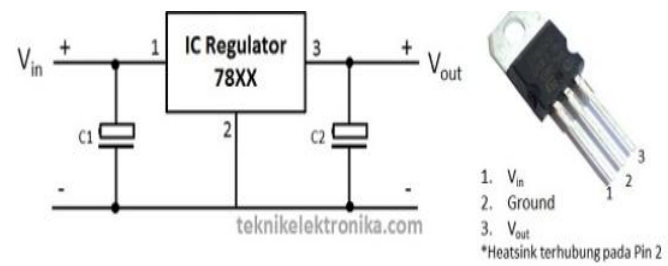

Gambar 5 Rangkaian dasar IC voltage regulator

Pada gambar 5 dapat dilihat IC 78xx yang memiliki tiga kaki dimana dari tampak depan, kaki pertama (kaki paling kiri jika dilihat dari depan) adalah input tegangan (positif untuk seri 78xx dan Negatif Untuk seri 79xx), kaki berikutnya atau kaki kedua merupakan ground atau pentanahan, dan kaki ketiga sebagai output tegangan. IC ini dapat dipasok dengan tegangan input berapa saja di atas tegangan output yang diinginkan yaitu pada tegangan maksimum 35 volt bahkan hingga 40 volt tergantung pada tipe dan merek dari IC, dengan variasi arus tegangan output adalah 1 ampere atau 1,5 ampere.

\section{E. Liquid Crystal Display (LCD)}

LCD (Liquid Crystal Display) merupakan salah satu tipe display elektronik yang dibuat menggunakan teknologi CMOS logic yang bekerja dengan mentransmisikan cahaya dari belakang latar atau disebut backlight ataupun memantulkan cahaya yang ada di sekelilingnya terhadap cahaya dari depan latar frontlight. LCD berfungsi sebagai penampil data baik dalam bentuk karakter, huruf, angka ataupun grafik. IC mikrokontroler terdapat dalam modul LCD yang berfungsi sebagai pengendali tampilan karakter yang dilengkapi dengan memori dan register.

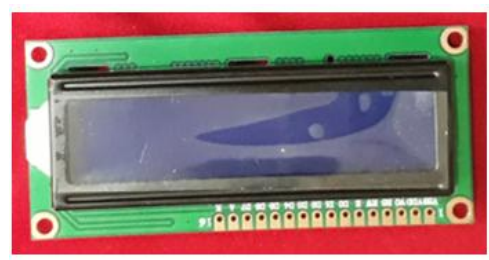

Gambar 6 LCD 16 X 2

Pin kaki atau jalur input dan kontrol dalam suatu LCD (Liquid Crystal Display) diantaranya adalah :

1) Pin RS (Register Select) merupakan indikator atau yang menentukan jenis instruksi yang diberikan yakni instruksi data ataupun perintah. Untuk membedakan kedua jenis instruksi tersebut maka dibedakan menjadi tipe logic low dan logic high. Pada logic high akan menunjukan data sedangkan pada logic high menunjukkan perintah.

2) Pin data merupakan jalur untuk memberikan data karakter yang ingin ditampilkan pada layar. Pin pada LCD dapat dihubungkan dengan bus data dari rangkaian lain seperti mikrokontroler dengan lebar data 8 bit sehingga layar akan menampilkan data sesuai dengan program yang di-upload pada mikrokontroler.

3) Pin R/W (Read Write) merupakan jalur yang memberikan pilihan instruksi berupa pembacaan ataupun penelitian data. Jika instruksi high maka perintah untuk membaca data sementara pada instruksi low maka perintah untuk menulis data.

4) Pin VLCD merupakan jalur yang berfungsi untuk mengatur kecerahan tampilan (kontras) dimana pin ini dihubungkan dengan potensiometer, namun jika tidak dibutuhkan 
untuk pengaturan kecerahan maka dapat dihubungkan langsung ke ground.

5) Pin VDD, merupakan jalur tegangan masukan 5 volt yaitu berasal dari catu daya atau modul mikrokontroler.

6) Pin E (Enable) digunakan untuk mengijinkan data masuk atau data keluar.

Pada perancangan alat ini digunakan LCD tipe 16 × 2 matriks, artinya LCD ini bisa menampilkan karakter dalam 2 baris dan 16 kolom karakter data keluaran berupa ADC dan status dari kelayakan oli tersebut.

\section{F. Modul Sensor Infrared (IR)}

Komponen penting pada sensor infrared (IR sensor) adalah bagian pemancar sinar infra merah (infrared) dan bagian penerima pantulan sinar infrared. Untuk memancarkan sinar infra merah maka digunakan Infrared Light Emitting Diode ( IR LED) sementara untuk menerima pantulan cahaya dari sinar merah (infrared) dibutuhkan photodiode. Gambar 7 menunjukkan tampilan dari modul sensor infrared dimana terdapat bagian pemancar LED infrared, penerima pantulan sinar infrared dari obyek yang dituju oleh arah pemancar dan juga IC pembanding tegangan yaitu IC LM393.

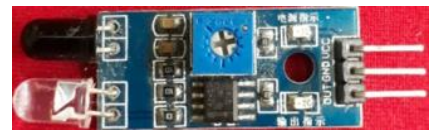

Gambar 7 Sensor IR

\section{a. Infrared LED}

Pada modul sensor $I R$ terdapat infrared LED yang berfungsi sebagai pemancar cahaya sinar merah (infrared) yang merupakan cahaya tidak tampak. Infrared hanya dapat dideteksi radiasi cahayanya dengan menggunakan spektroskop cahaya. Radiasi cahaya yang dikeluarkan pada infrared LED terlihat pada pada spektrum elektromagnet dengan panjang gelombang antara $700 \mathrm{~nm}$ hingga $1 \mathrm{~mm}$ dan berada pada spektrum berwarna merah. Hal ini menyebabkan cahaya infrared tidak dapat dilihat secara kasat mata namun radiasi yang dikeluarkan menghasilkan panas yang dapat dirasakan.
Meskipun cahaya infrared memiliki panjang gelombang yang sangat panjang namun cahaya tersebut memiliki karakteristik yang sama dengan cahaya tampak karena cahaya infrared tidak dapat menembus bahanbahan yang tidak dapat melewatkan cahaya yang nampak.

\section{b. Photodiode}

Photodiode merupakan jenis dioda yang bisa mendeteksi keberadaan cahaya baik cahaya langsung maupun cahaya yang dipantulkan oleh benda tertentu. Photodiode mengubah cahaya menjadi arus, artinya photodiode akan mengalirkan arus jika ada cahaya yang mengenainya. Besarnya konduktivitas photodiode tergantung dari kuat cahaya yang masuk. Semakin besar intensitas cahaya maka akan semakin besar arus yang melewatinya.

Bahan semikonduktor menjadi penyusun pada sebuah photodiode. Adapun bahan semikonduktor tersebut antara lain adalah Silicon, Germanium, Indium gallium arsenide dan Mercury cadmium telluride.

Bagian terpenting dalam cara kerja sebuah photodiode terletak pada P-N junction dan area penipisan (Depletion Region). Daerah kerja photodiode dibuat ketika doping tipe $\mathrm{N}$ bertemu dengan doping tipe $\mathrm{P}$ dengan hole-nya sehingga terisi elektron dari semikonduktor tipe $\mathrm{N}$ tersebut. Arus listrik akan timbul setelah adanya pertemuan antara elektron dan hole. Intensitas cahaya masuk pada photodiode haruslah dalam jumlah yang cukup sehingga dapat membentuk pasangan elektron dan hole. Pasangan elektron dan hole inilah yang meyebabkan aliran arus listrik. Arus listrik akan semakin besar jika intensitas cahaya yang masuk semakin tinggi hal ini akan berbanding terbalik dengan nilai perlawanan resistansi yang semakin rendah jika jumlah cahaya yang semakin besar. Sementara itu jika cahaya yang diterima oleh photodiode kecil intensitasnya maka nilai resistansi pada photodiode akan semakin besar yang menyebabkan tegangan output semakin kecil.

\section{c. IC LM393}

IC LM393 merupakan IC komperator yang berfungsi untuk membandingkan 
tegangan yang masuk pada saluran input dan tegangan masuk pada saluran referensi. Tegangan keluaran yang dihasilkan adalah berupa tegangan low atau high sesuai dengan perbandingan Vin dan Vref.

\section{METODOLOGI PENELITIAN}

\section{A. Alat dan Bahan}

Dalam pembuatan perancangan alat pendeteksi kelayakan oli pada sepeda motor berbasis Arduino Uno ATmega328 ini tidak terlepas dari alat dan bahan yang digunakan. Adapun alat yang digunakan adalah sebagai berikut :

1) Komputer (Laptop).

2) Kabel USB Downloader.

3) Toolset.

4) Solder.

5) Multimeter.

Sementara bahan yang diperlukan dalam perancangan alat pendeteksi kelayakan oli pada sepeda motor berbasis Arduino Uno ATmega328 ini adalah sebagai berikut :

1) Arduino Uno ATmega328.

2) Modul sensor IR.

3) Liquid Crystal Display 16 × 2.

4) Potensiometer $2 K \Omega$.

5) Kabel jumper.

6) Protoboard.

7) Oli motor dengan 3 variasi kondis

\section{B. Alir Penelitian}

Dalam melakukan penelitian diperlukan sistematika proses pembuatannya. Adapun proses demi proses yang dilakukan dituangkan pada diagram alir penelitian. Diagram alir tersebut mencakup seluruh proses pembuatan tulisan mulai dari menentukan obyek sampai pada penarikan kesimpulan dari pengambilan dan analisa data yang diperoleh dari alat. Dari kesimpulan yang diperoleh maka dapat diketahui keberhasilan dari alat yang telah dirancang dan dibuat. Gambar 8 menampilkan diagram alir penelitian

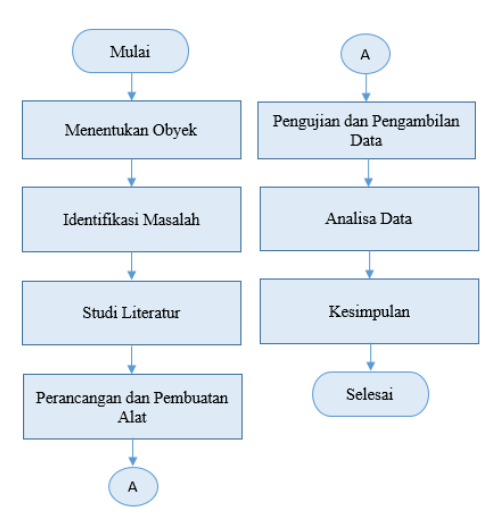

Gambar 8 Alir Penelitian

\section{Perancangan Sistem}

Pada perancangan alat pendeteksi kelayakan oli pada sepeda motor ini, peneliti menggunakan blok diagram yang menunjukkan skema alat secara garis besar. Diagram blok ini memiliki peran yang sangat penting sehingga dapat memberikan kemudahan dalam memahami prinsip kerja alat dan memberikan kemudahan dalam pengambilan data dan menganilisa setiap sub sistem yang telah dirancang.

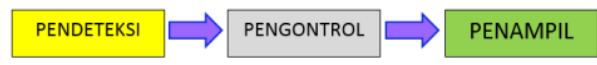

Gambar 9 Diagram Blok

\section{a. Sistem pendeteksi}

Merupakan suatu sistem yang bekerja untuk melakukan proses pendeteksi tentang obyek yang diamati yaitu oli variasi kondisi menurut jauh perjalanan dari sepeda motor.

\section{b. Sistem pengontrol}

Merupakan suatu sistem yang bekerja untuk menentukan apakah kondisi obyek yang diamati memenuhi kriteria yang ditetapkan, dalam penelitian ini kriteria yang ditetapkan adalah kondisi layak atau tidak layak.

c. Sistem penampil

Merupakan suatu sistem yang bekerja untuk menampilkan hasil dari keputusan sistem pengontrol tentang kondisi dari obyek yang diamati. 


\section{Skematik Diagram}

Untuk mengetahui konektifitas dari blok pendeteksi, pengontrol dan penampil maka diperlukan suatu skematik diagram yang dapat menampilkan keseluruhan sistem.

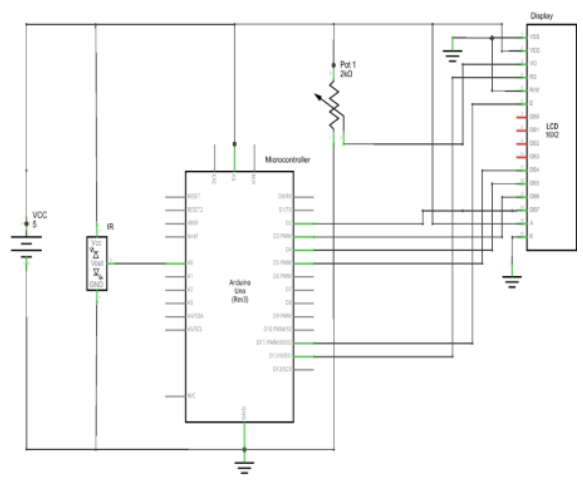

Gambar 10 Skematik Diagram Sistem

\section{E. Alir Sistem}

Setelah menampilkan alir penelitian berikut peneliti akan menampilkan bagaimana alir sistem peralatan yang akan dibuat. Alir sistem ini dibuat untuk menunjukkan bagaimana sistematika peralatan. Diagram alir sistem ditunjukkan pada gambar 11.

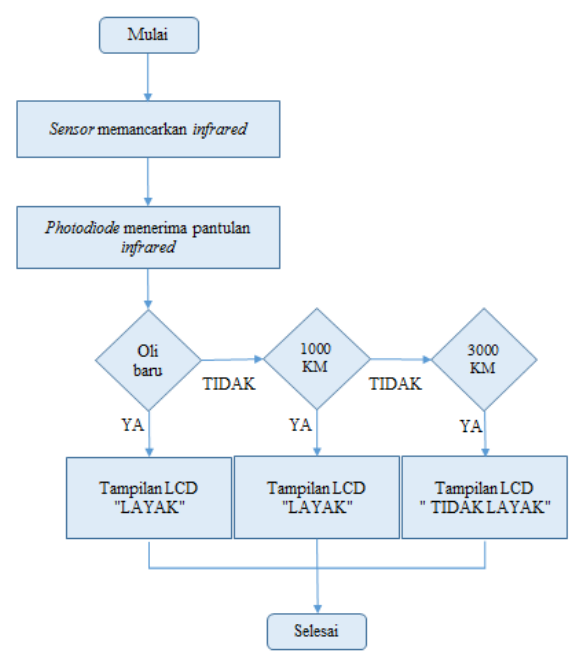

Gambar 11 Alir Sistem

\section{F. Pengujian dan Pengambilan Data}

Untuk mengetahui apakah alat dapat berfungsi dengan baik sesuai dengan perancangan yang telah dibuat maka langkah selanjutnya adalah melakukan proses pengujian alat. Proses pengujian peralatan dilakukan setelah pembuatan alat selesai. Selain untuk membuktikan alat berfungsi dengan baik, proses pengujian juga bertujuan unutk memeriksa masing-masing komponen dapat bekerja sesuai dengan fungsinya masingmasing. Proses perbaikan harus segera dilakukan bilamana terdapat salah satu atau beberapa komponen tidak bekerja secara optimal dan proses perbaikan tersebut mencakup pada pengecekan pada rangkaian (hardware) dan juga program yang digunakan (software). Pergantian komponen dilakukan jika pada proses pengecekan tidak ditemukan kesalahan baik pada rangkaian maupun pada program yang digunakan.

Setelah proses pengujian selesai dilakukan, maka tahap selanjutnya adalah proses pengambilan data. Proses pengambilan data dilakukan dengan melakukan skenario pengambilan data dan pengujian sebagai berikut :

a. Pengambilan oli berdasarkan jarak tempuh kendaraan.

Pada skenario ini bertujuan untuk mendapatkan tiga variasi jenis oli yang akan digunakan sebagai obyek penelitan sesuai dengan jarak tempuh kendaraan pada saat menggunakan oli tersebut.

b. Pengujian nilai tegangan pada sensor IR terhadap oli

Pengujian ini bertujuan untuk mengetahui tegangan keluaran yang dihasilkan pada modul sensor $I R$ pada ketiga jenis oli yang menjadi obyek penelitian.

c. Pengujian nilai ADC yang ditampilkan pada LCD

Tahap pengujian ini bertujuan untuk menampilkan nilai ADC (Analog to Digital Converter) pada LCD setelah sensor membaca tegangan dari masing-masing jenis oli.

d. Pengujian status kelayakan yang ditampilkan pada LCD.

Pengujian ini bertujuan untuk menampilkan status kelayakan oli pada LCD yang merupakan refleksi dari perbedaan nilai 
ADC pada masing-masing jenis oli yang menjadi obyek penelitian.

\section{HASIL DAN PEMBAHASAN}

\section{A. Hasil Pengambilan Data}

Pengambilan data merupakan sebuah proses yang dilakukan untuk mengetahui parameter-parameter yang terdapat pada sistem yang telah dirancang. Parameter-parameter ini nantinya akan dianalisa sehingga dapat digunakan untuk memperbaiki sistem yang telah dibuat sampai kondisi maksimal. Pengambilan data dilakukan pada semua bagian sistem baik pada perangkat keras maupun perangkat lunak.

Peneliti telah merancang dan membuat alat pendeteksi kelayakan oli pada sepeda motor berbasis Arduino Uno menggunakan mikrokontroler ATmega328. Alat ini ditelah selesai dibuat dan berfungsi dalam pengujian yang telah dilakukan oleh peneliti. Gambar 12 merupakan tampilan alat pendeteksi kelayakan oli pada sepeda motor berbasis Arduino Uno.

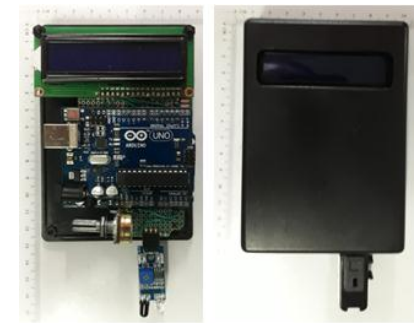

Gambar 12 Alat pendeteksi kelayakan oli

a. Pengambilan Oli Berdasarkan Jarak

Tempuh Kendaraan

Peneliti melakukan pengambilan sample tiga jenis kondisi oli dimana terdapat kondisi oli baru, oli yang telah dipergunakan sejauh $1000 \mathrm{KM}$ dan oli yang telah dipergunakan sejauh 3000 KM. Untuk mendapatkan ketiga kondisi diatas maka peneliti melakukan pemakaian oli pada kendaraan sepeda motor sejauh $1000 \mathrm{KM}$ dan 3000 KM secara split. Adapun waktu yang dibutuhkan untuk mencapai kondisi tersebut di atas dituliskan pada tabel 2 .

Tabel 2 Waktu dibanding jarak tempuh

\begin{tabular}{|c|c|c|}
\hline No & Tanggal & Jarak Tempuh \\
\hline 1 & 18 Februari 2019 & 0 \\
\hline 2 & 2 April 2019 & $1000 \mathrm{KM}$ \\
\hline 3 & 14 Juli 2019 & $3000 \mathrm{KM}$ \\
\hline
\end{tabular}

tempuh

Dengan adanya perbedaan jarak

\begin{tabular}{|c|c|c|c|}
\hline 5 & $0,11 \mathrm{v}$ & $0,11 \mathrm{v}$ & $4,72 \mathrm{v}$ \\
\hline 6 & $0,11 \mathrm{v}$ & $0,11 \mathrm{v}$ & $4,71 \mathrm{v}$ \\
\hline 7 & $0,11 \mathrm{v}$ & $0,10 \mathrm{v}$ & $4,72 \mathrm{v}$ \\
\hline 8 & $0,11 \mathrm{v}$ & $0,11 \mathrm{v}$ & $4,72 \mathrm{v}$ \\
\hline 9 & $0,10 \mathrm{v}$ & $0,11 \mathrm{v}$ & $4,72 \mathrm{v}$ \\
\hline 10 & $0,11 \mathrm{v}$ & $0,11 \mathrm{v}$ & $4,72 \mathrm{v}$ \\
\hline$\%$ Error & $10 \%$ & $10 \%$ & $20 \%$ \\
\hline
\end{tabular}

mengakibatkan perubahan warna pada ketiga kondisi oli. Perbedaan warna dari oli dapat dilihat pada gambar 13 .

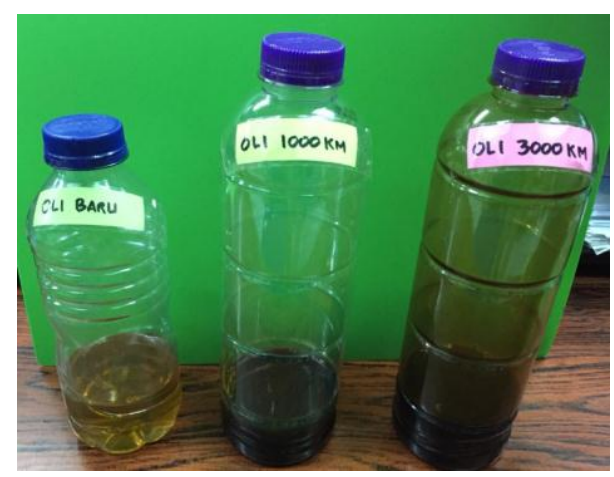

Gambar 13 Perbedaan warna oli

b. Pengujian nilai tegangan pada sensor IR terhadap oli

Pengujian ini dilakukan untuk mengetahui perbedaan tegangan output pada sensor IR sebagai akibat perubahan warna pada obyek. Sesuai dengan batasan masalah peneliti melakukan pengujian pada kondisi oli baru ( $0 \mathrm{KM}$ ), oli pemakaian 1000 $\mathrm{KM}$, dan oli pemakaian $3000 \mathrm{KM}$. Metode pengukuran dilakukan dengan multimeter di mana probe positif pada multimeter (warna merah) dihubungkan dengan pin out pada sensor IR dan probe negatif pada multimeter (warna hitam) dihubungkan dengan pin gnd pada sensor IR. 
Sigma Teknika, Vol.2, No.2 : 179-191

November 2019

E-ISSN 2599-0616

P ISSN 2614-5979
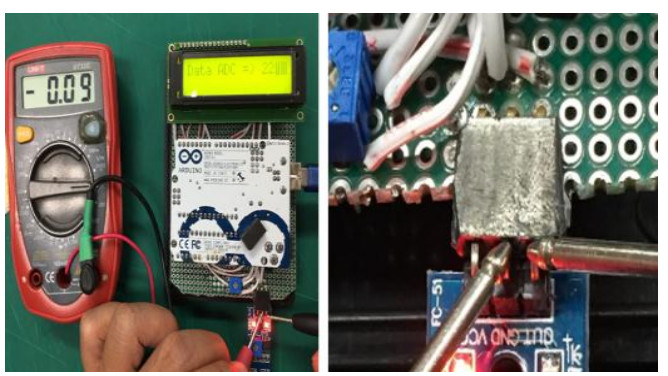

Gambar 14 Pengukuran tegangan output

Dengan melakukan pengukuran tersebut diatas maka diperoleh nilai tegangan pada ketiga kondisi oli yang dituliskan pada tabel 3 .

Tabel 3 Nilai tegangan output

\begin{tabular}{|c|c|c|c|}
\hline Percobaan & Baru & $1000 \mathrm{~km}$ & $3000 \mathrm{~km}$ \\
\hline 1 & $0,11 \mathrm{v}$ & $0,11 \mathrm{v}$ & $4,72 \mathrm{v}$ \\
\hline 2 & $0,11 \mathrm{v}$ & $0,11 \mathrm{v}$ & $4,72 \mathrm{v}$ \\
\hline 3 & $0,11 \mathrm{v}$ & $0,11 \mathrm{v}$ & $4,72 \mathrm{v}$ \\
\hline 4 & $0,11 \mathrm{v}$ & $0,11 \mathrm{v}$ & $4,71 \mathrm{v}$ \\
\hline
\end{tabular}

c. Pengujian nilai ADC yang ditampilkan pada LCD

Pengujian data keluaran dilakukan untuk mengamati perubahan nilai ADC (Analog Digital Converter) yang ditampilkan oleh LCD 16 x 2 terhadap perubahan warna pada ketiga kondisi oli di atas. Untuk menampilkan nilai ADC diperlukan Arduino Uno yang telah diisi dengan program menggunakan bahasa C. Setelah melakukan pemrograman maka akan diperoleh data ADC yang tertera pada layar LCD sesuai dengan perbedaan warna pada ketiga kondisi oli yang dituliskan pada tabel 4 .

Tabel 4 Nilai ADC terhadap oli

\begin{tabular}{|c|c|c|c|}
\hline Percobaan & Baru & $1000 \mathrm{~km}$ & $3000 \mathrm{~km}$ \\
\hline 1 & 24 & 24 & 1017 \\
\hline 2 & 24 & 24 & 1018 \\
\hline 3 & 25 & 24 & 1018 \\
\hline 4 & 24 & 24 & 1018 \\
\hline 5 & 24 & 25 & 1018 \\
\hline 6 & 24 & 24 & 1018 \\
\hline 7 & 24 & 24 & 1017 \\
\hline 8 & 24 & 25 & 1018 \\
\hline 9 & 24 & 24 & 1018 \\
\hline 10 & 24 & 24 & 1018 \\
\hline$\%$ Error & $10 \%$ & $20 \%$ & $20 \%$ \\
\hline
\end{tabular}

d. Pengujian status kelayakan yang ditampilkan pada LCD

Pada tahap pengujian ini diperoleh data status tentang ketiga kondisi dari oli yang digunakan apakah oli menunjukkan kondisi layak atau tidak layak. Nilai ADC dari sensor akan dikonversikan ke dalam dua kondisi yaitu LAYAK dan TIDAK LAYAK yang ditunjukkan pada tabel 5.

Tabel 5 Pembacaan status kelayakan oli

\begin{tabular}{|c|c|c|c|}
\hline Percobaan & Baru & $1000 \mathrm{~km}$ & $3000 \mathrm{~km}$ \\
\hline 1 & LAYAK & LAYAK & TIDAK LAYAK \\
\hline 2 & LAYAK & LAYAK & TIDAK LAYAK \\
\hline 3 & LAYAK & LAYAK & TIDAK LAYAK \\
\hline 4 & LAYAK & LAYAK & TIDAK LAYAK \\
\hline 5 & LAYAK & LAYAK & TIDAK LAYAK \\
\hline 6 & LAYAK & LAYAK & TIDAK LAYAK \\
\hline 7 & LAYAK & LAYAK & TIDAK LAYAK \\
\hline 8 & LAYAK & LAYAK & TIDAK LAYAK \\
\hline 9 & LAYAK & LAYAK & TIDAK LAYAK \\
\hline 10 & LAYAK & LAYAK & TIDAK LAYAK \\
\hline$\%$ Error & 0 $\%$ & $0 \%$ & $0 \%$ \\
\hline
\end{tabular}

\section{B. Pembahasan}

a. Perubahan nilai tegangan sensor terhadap oli

Setelah melakukan pengujian alat maka diperoleh nilai tegangan output yang berubah pada setiap kondisi oli. Hal ini disebabkan nilai resistansi yang ada pada photodiode berubah sesuai dengan warna dari permukaan oli.

Dari rumus dasar pembagi tegangan yang dituliskan dalam teori dasar dapat diperoleh nilai resistansi pada photodiode yang berubah akibat perubahan warna pada oli yang digunakan sebagai obyek.

1) Pada oli baru (pemakaian $0 \mathrm{KM}$ )

Pada kondisi oli baru tegangan yang ditampilkan pada multimeter adalah Vout $=$ $0,11 \mathrm{v}$ dengan tegangan input Vin $=4,76 \mathrm{v}$ dengan nilai resistansi dari diode adalah tetap $\mathrm{R} 1=1100 \Omega$. Untuk memperoleh nilai resistansi pada photodiode $\mathrm{R} 2$ maka digunakan rumus : 
$\frac{\text { Vin }}{\text { Vout }} \times \mathrm{R} 2-\mathrm{R} 2=\mathrm{R} 1$

Dengan memasukkan nilai parameter yang diketahui maka diperoleh nilai resistansi R2 sebagai berikut :

$$
\begin{aligned}
& \frac{4,76 v}{0,11 v} \times \mathrm{R} 2-\mathrm{R} 2=1100 \Omega \\
& 43,27 \mathrm{R} 2-\mathrm{R} 2=1100 \Omega \\
& 42,27 \mathrm{R} 2=1100 \Omega \\
& \mathrm{R} 2=26,02 \Omega
\end{aligned}
$$

2) Pada oli pemakaian $1000 \mathrm{~km}$

Pada kondisi oli $1000 \mathrm{~km}$ nilai tegangan yang ditampilkan pada multimeter adalah Vout $=0,11 \mathrm{v}$ dengan tegangan input Vin $=4,76 \mathrm{v}$ dengan nilai resistansi dari dioda $\mathrm{R} 1=1100 \Omega$. Dengan memasukkan nilai parameter yang diketahui maka diperoleh nilai resistansi R2 sebagai berikut :

$$
\begin{aligned}
& \frac{4,76 v}{0,11 v} \times \mathrm{R} 2-\mathrm{R} 2=1100 \Omega \\
& 43,27 \mathrm{R} 2-\mathrm{R} 2=1100 \Omega \\
& 42,27 \mathrm{R} 2=1100 \Omega
\end{aligned}
$$

$\mathrm{R} 2=26,02 \Omega$

\section{3) Pada oli pemakaian $3000 \mathrm{KM}$}

Pada kondisi oli $3000 \mathrm{~km}$ nilai tegangan yang ditampilkan pada multimeter adalah Vout $=4,72 \mathrm{v}$ dengan tegangan input Vin $=4,76 \mathrm{v}$ dengan nilai resistansi dari dioda $\mathrm{R} 1=1100 \Omega$. Dengan memasukkan nilai parameter yang diketahui maka diperoleh nilai resistansi R2 sebagai berikut :

$$
\begin{aligned}
& \frac{4,76 v}{4,72 v} \times \mathrm{R} 2-\mathrm{R} 2=1100 \Omega \\
& 1,00847 \mathrm{R} 2-\mathrm{R} 2=1100 \Omega \\
& 0,00847 \mathrm{R} 2=1100 \Omega \\
& \mathrm{R} 2=129.870 \Omega
\end{aligned}
$$

\section{b. Pembacaan ADC pada LCD}

Alat ini menggunakan mikrokontroler ATmega328 menggunakan 10 bit dengan maksimum ADC adalah 1023. Pada pengujian alat ini diperoleh nilai ADC yang rendah pada kondisi oli baru dan oli yang digunakan pada jarak $1000 \mathrm{KM}$ sebaliknya nilai ADC akan tinggi pada saat sensor membaca kondisi oli yang telah dipergunakan pada jarak $3000 \mathrm{KM}$. Hal tersebut disebabkan adanya perbedaan tegangan pada photodiode pada ketiga kondisi oli tersebut. Perbedaan nilai ADC tersebut digunakan untuk menentukan kelayakan dari oli.

\section{KESIMPULAN DAN SARAN}

\section{A. Kesimpulan}

Setelah sistem telah dibuat dan proses pegujian sistem selesai dilakukan, mengacu dengan rumusan masalah yang peneliti telah tentukan maka dapat disimpulkan beberapa hal sebagai berikut :

1. Data pembacaan sensor berhasil digunakan untuk menunjukkan status kelayakan oli dengan persentase error $0 \%$ dari perbedaan warna oli setelah digunakan pada jarak $0 \mathrm{~km}$, $1000 \mathrm{~km}$ dan $3000 \mathrm{~km}$.

2. Dengan menggunakan Arduino Uno Atmega328 perubahan nilai sensor dapat direfleksikan kepada penampil dalam hal ini LCD untuk memberi keterangan kepada pemakai alat tentang kelayakan dari oli yang telah digunakan.

\section{B. Saran}

Dalam penyusunan tulisan dan pembuatan alat ini peneliti mengakui masih jauh dari suatu kesempurnaan. Oleh sebab itu peneliti berharap adanya pengembangan bahkan terciptanya alat baru yang nantinya semakin mendekati akurasi dan mencakup banyak variasi obyek yang diteliti. Berikut saran dari peneliti untuk pengembangan dimasa yang akan datang :

1. Dapat dilakukan pengujian untuk kondisi oli lebih dari tiga kondisi yakni menggunakan jenis sensor yang berbeda.

2. Dilakukan pengembangan alat pendeteksi kelayakan oli pada kendaraan roda empat karena jenis oli yang digunakan memiliki visikositas yang berbeda dengan oli sepeda motor. 
Sigma Teknika, Vol.2, No.2 : 179-191

November 2019

E-ISSN 2599-0616

P ISSN 2614-5979

\section{DAFTAR PUSTAKA}

Kendaraan Bermotor. Indonesia, (2016).

[1] Bambang Supeno, Puranggi Widiyastika Septi, M. Agung Prawira Negara. "Perancangan Sistem Pengukuran Kualitas Oli Pada Kendaraan Sepeda Motor Berbasis Logika Fuzzy". Universitas Jember Digital Repository, (2014). http://repository.unej.ac.id/handle/123 $456789 / 68052 .\{14 / 12 / 2018\}$

[2] Bishop Owen. "Dasar - Dasar Elektronika", Jakarta : Penerbit Erlangga, (2004).

[3] Darmanto. "Mengenal pelumas pada mesin“, E-Jurnal Momentum Vol. 7 No. 1, Jakarta. (2011).

[4] Freedy. " $L C D$ ", Enginner Garage (2014).

[5] Hendri. "Pengenalan Arduino Uno", Belajar Arduino, (2015).

[6] Masput. "Pengertian Adaptor, fungsi dan jenisnya", Masputz.com, (2015). http://www.masputz.com/2015/08/pen gertian-adaptor-fungsi-dan-jenis.html $\{14 / 12 / 2018\}$

[7] Prasetyo Gatot Budi, Qomaruddi. "Rancang Bangun Alat Ukur Visikositas Oli Motor Bebek 4 Tak Menggunakan Laser",Lokakarya Ilmiah Nasional Aplikasi Optik dan Fotonik (LINOF), Serpong, Tangerang Selatan.(2015).

[8] Sunil. "How to use the FC 51 Infrared proximity/obstacle avoidance sensor with Arduino", Surtrtech, (2018).

[9] Tegar. "Prinsip Kerja DC Power supply (Adaptor)”, Teknik Elektronika, (2016).https://teknikelektronika.com/p rinsip-kerja-dc-power-supply-adaptor/, $\{5 / 03 / 2019\}$

[10] Yamaha. "Penyetelan dan perawatan berkala", Buku Petunjuk Pengguna 